Agrovoc descriptors: aphidoidea; watermelons; citrullus lanatus; mulches; pest control; traps

Agris category code: $\mathrm{H} 10$

\title{
Aphid population in watermelon (Citrullus lanatus Thunb.) production
}

\author{
Katja ŽANIĆ ${ }^{1}$, Dean BAN ${ }^{2}$, Marisa ŠKALJAC ${ }^{3}$, Gvozden DUMIČIĆ ${ }^{4}$, Smiljana GORETA BAN ${ }^{5}$, \\ Dragan ŽNIDARČIČ́
}

Received: March 16, 2009; accepted: June 22, 2009.

Delo je prispelo 16. marca 2009; sprejeto 22. junija 2009.

\begin{abstract}
The aim of this study was to compare the effect of PE black mulch with bare soil and hay cover against winged aphid number. In order to create management strategy in watermelon, flight dynamics of aphid population was recorded. The field experiment was set up as a randomized block design in three replications at Pula in Mediterranean region of Croatia. Aphids were collected weekly using yellow water metal traps. There were six sampling dates starting from 19 May until mulch was covered by plant canopy. We found significant difference in aphid number among the sampling dates as a result of their population dynamics on watermelon. The catches of two assessments in the second half of May were more numerous than during assessments in June. The flight maximum was recorded on 26 May and the population density significantly decreased from 9 June. There was not much effect of mulch on aphid number. However, at the peak of aphid population hay cover attracted 13\% (26 May) and $18 \%$ (2 June) more aphids compared to bare soil.
\end{abstract}

Key words: Aphidae, watermelon, Citrullus lanatus, PE black film, hay mulch

\section{IZVLEČEK}

LISTNE UŠI NA LUBENICAH (Citrullus lanatus Thunb.)

Cilj naše raziskave je bil ugotoviti, kako PE črna folija $\mathrm{v}$ primerjavi z golimi tlemi in tlemi, prekritimi s senom, vpliva na razširjenost listnih uši na lubenicah. Tako smo $z$ ugotavljanjem številčnega stanja uši želeli prilagoditi tehnolgijo gojenja lubenic $\mathrm{v}$ boju proti tem škodljivcem. Poljski poskus, ki je bil leta 2008 zasnovan po metodi naključnih blokov v treh ponovitvah, je bil postavljen v okolci Pulja v primorskem delu Hrvaške. Prisotnost uši smo s preštevanjem na rumenih kovinskih vabah ugotavljali vsak teden. Od 19. maja do trenutka, ko so listi lubenic prekrili tla, smo opravili šest preštevanj. Med posameznimi datumi smo ugotovili značilno razliko med številom uši na vabah, ki je bila posledica njihove populacijske dinamike na rastlinah. Število uši $\mathrm{v}$ dveh preštevanjih $\mathrm{v}$ drugi polovici maja je bilo znato večje od števila uši naštetih v juniju. Največji nalet uši je bil ugotovljen 26. maja. Njihova razširjenost pa se je značilno zmanjšala do 9. junija. Način zastiranja tal ni statistično značilno vplival na razširjenost uši. Poudariti pa je treba, da je na vrhuncu prisotnosti uši senena zastirka privabila $13 \%$ (26. maja) oz. $18 \%$ (2. junija) več uši, kot smo jih našteli v obravnavanjih na golih tleh.

Ključne besede: Aphidae, lubenice, Citrullus lanatus, PE črna folija, senena zastirka

\section{INTRODUCTION}

1 Institute for Adriatic Crops and Karst Reclamation, Put Duilova 11, CR-21 000 Split; e-mail: Katja.Zanic@krs.hr

2 Institute of Agriculture and Tourism, Carla Huguesa 8, CR-52 440 Poreč, Croatia

3 Institute for Adriatic Crops and Karst Reclamation, Put Duilova 11, CR-21 000 Split

4 Institute for Adriatic Crops and Karst Reclamation, Put Duilova 11, CR-21 000 Split

5 Institute for Adriatic Crops and Karst Reclamation, Put Duilova 11, CR-21 000 Split

${ }^{6}$ Biotechnical Faculty, University of Ljubljana, Jamnikarjeva 101, SI-1111 Ljubljana 
Following the trends in cultural practice, many growers have employed mulching, as a common practice and the most often used soil cover is the black polyethylene (PE) mulch (Goreta et al., 2005). The use of polyethylene mulches increase early and total yield of many vegetable such as strawberry (Fragaria $X$ ananas Duch.), tomato (Lycopersicon esculentum Mill.), pepper (Capsicum annuum L.), squash (Cucurbita pepo L.), potatoe (Solanum tubeosum L.) and melons (Cucumis and Citrullus spp.) (Soltani et al., 1995; Farias-Larios and Orozco-Santos, 1997b; White, 2003, 2004; Johnson et al., 2004). Many vegetable growers would prefer to use mulches that can be produced on-farm and incorporated into soil to build soil organic matter. Such organic plant waste include grasses, straw and hay.

According to Csizinszky et al. (1995), different mulch systems create a specific microenvironment around the plants. Compared to bare soil, changes in microenvironment include changes in root-zone temperature and in the quantity and quality of light reflected from the mulch surface back to leaves (Lamont, 1993).

The reflected energy from the mulches affects not only plant growth, development, yields, and the behaviour of insects that visit the plants (Kring and Shuster, 1992). Mulch systems may influence on aphid populations that landing in the crop. According to Farias-Larios and Orozco-Santos (1997a, 1997b) and Walters (1993), clear, black and white mulches reduce the aphid number compared to bare soil. Silver reflective mulch is superior to white, yellow, or black with yellow edges in reducing aphid population (Brown, 1993). The number of winged aphids per leaf is significantly higher on cantaloupe plants grown over bare soil than on those grown over reflective plastic or organic straw mulch (Summers et al., 2005). Straw mulch has been well studied in reducing pests infestation and virus incidence in several crops (Saucke and Döring, 2004; Trdan et al., 2008). Related to our observation, the use of straw mulch makes a problem in vegetable crops because of cereals germination. To avoid the cereals-weed appearance, organic mulch, hay was included in the experiment.

A number of aphid species have been recorded as Cucurbitaceae crops feeders (Millar, 1994; FariasLarios and Orozco-Santos, 1997a; Stapleton and Summers, 2002). The aim of this study was to compare the effect of PE black mulch versus bare soil and hay cover on aphid number in watermelon crop.

\section{MATERIAL AND METHODS}

Field experiment with watermelon (Citrullus lanatus [Thunb. ] Matsum \& Nakai), cv. Farao (S\&G Syngenta SeedsVegetables, Nederland/Belgie) was conducted at Valtura Pula $\left(44^{\circ} 52^{\prime} \mathrm{N}, 13^{\circ} 54^{\prime} \mathrm{E}, 10 \mathrm{~m}\right.$ elevation) in Mediterranean region of Croatia, during 2008.

The treatments (PE black mulch, bare soil and hay cover) were arranged in a randomized complete block design with three replications. The hand planting was done on 9 May, 2008. The rows were $1.5 \mathrm{~m}$ apart and in-row plant spacing was $1.0 \mathrm{~m}$. Each plot (4.5 m wide $\times 10 \mathrm{~m}$ long) was consisted of three rows $(1.0 \mathrm{~m}$ wide $\times 10 \mathrm{~m}$ long). Black PE film was $0.02 \mathrm{~mm}$ thick and $120 \mathrm{~cm}$ width (Ginegar Plastics Products Ltd., Kibbutz Ginegar, Israel). The black mulch was applied using mulch-laying equipment, while the hay was spread by hand at $50 \mathrm{~kg}$ per plot in a thick layer $(20 \mathrm{~cm})$. Standard cultural and pesticide practice for commercial watermelon production were applied. The average growing period rainfall is $320.0 \mathrm{~mm}$ and cumulated temperatures were $520.6{ }^{\circ} \mathrm{C}$.

In order to create management strategy in watermelon, flight dynamics of aphid population was recorded. Winged aphids were collected weekly using customized Moericke yellow water metal trap $(60 \mathrm{~cm} \times 60 \mathrm{~cm} \times 12 \mathrm{~cm})$. The metal pans, with a sink-hole and faucet in the middle of a small pyramidal bottom, were placed on legs $40 \mathrm{~cm}$ above soil surface in the middle of the plot. There were six sampling dates starting from 19 May until mulch became covered by the plant canopy. Depending on environmental conditions water was added in the pans during the week. Collected material was inspected and aphids were separated using a stereomicroscope (Zeiss, Stemi 2000).

Data were tested by ANOVA (Stat View) and treatments were compared with LSD test at $\mathrm{P} \leq 0.05$.

\section{RESULTS AND DISCUSSION}

The significant difference in aphid number among the sampling dates was found as a result of their population dynamics on watermelon (Fig. 1). The catches of two assessments in the second half of May (19 and 26 May) were more numerous than during assessments in June.
The flight maximum was recorded on 26 May and the population density significantly decreased from 9 June.

Compared to our unpublished data, the results obtained at Pula are not coincidence with aphid flight dynamic recorded at Opuzen $\left(43^{\circ} 00^{\prime} \mathrm{N}, 17^{\circ} 34^{\prime} \mathrm{E}, 3 \mathrm{~m}\right.$ elevation). 
That results indicate the aphid flight in watermelon field at Opuzen starts at the beginning of May and increases at the beginning of June, with maximum at 9 June (2004, 2005).

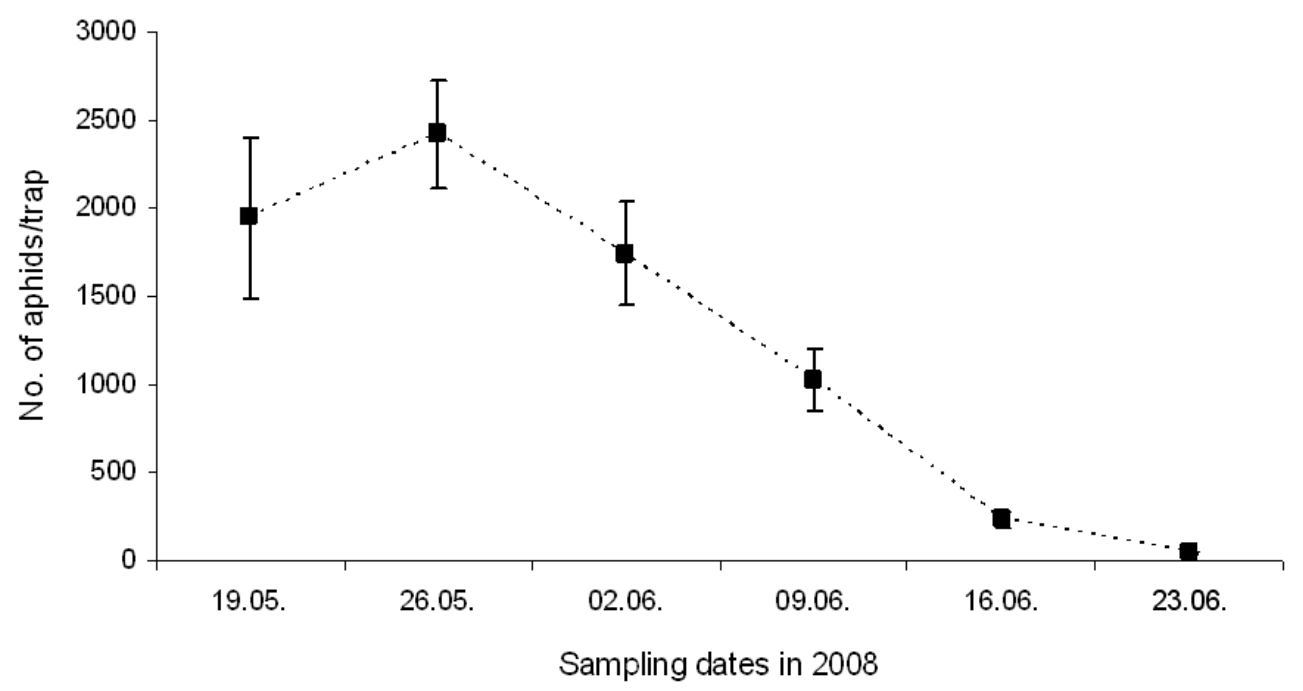

Figure 1: Aphid population dynamics in watermelon field at Pula (2008)

There was not much effect of mulch on aphid number (Fig. 2). The numbers of aphids captures during the sampling were too variable to detect the differences between the mulches. The results were obtained under field conditions for the cultivation of watermelon crops, and probably are linked to aphid biology and ecology, sampling date and season, and the influence of environmental factors, which are particularly characterised by wind pressure.
However, at the peak of aphid population hay cover attracted 13\% (26 May) and 18\% (2 June) more aphids compared to bare soil. According to our unpublished data, the overall spring seasonal averages of aphid number showed that fewer winged aphids were consistently found on black and clear mulches compared to brown, green and white ones in 2004 and 2005 at Opuzen. The less attractiveness of black mulch to aphids was not confirmed in the experiment conducted at Pula.

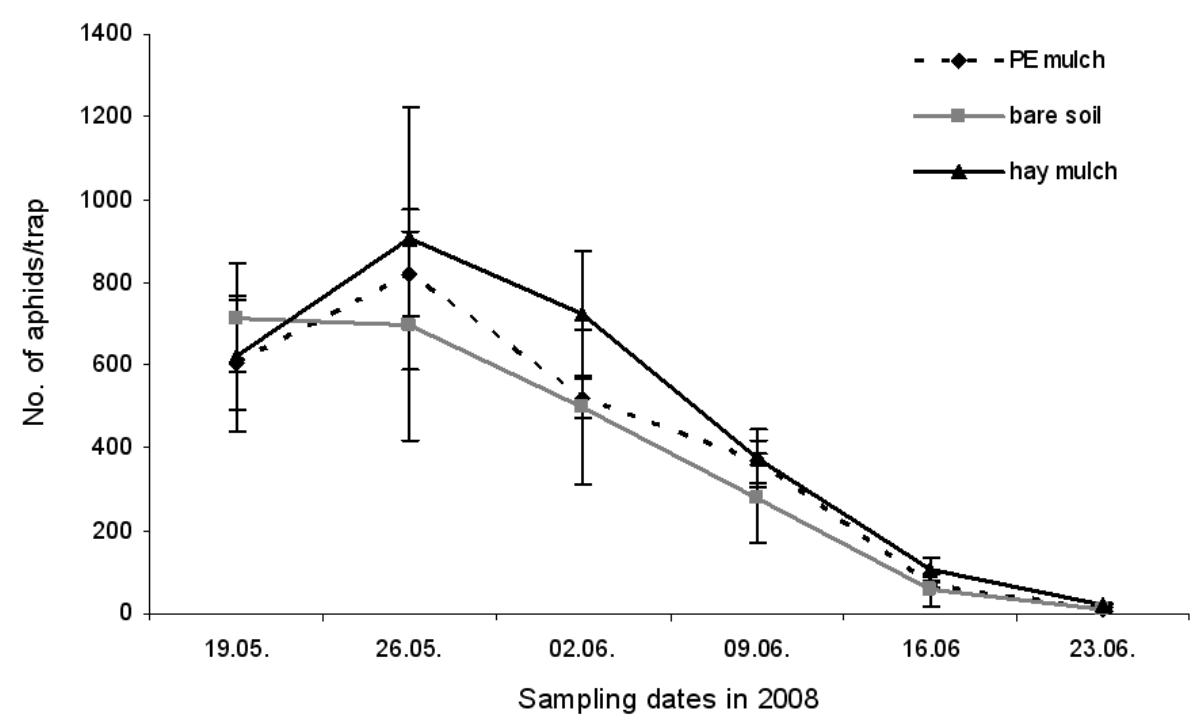

Figure 2: The number of winged aphids caught in yellow water traps in mulched watermelon or grown on bare soil at Pula (2008) 


\section{CONCLUSIONS}

The most imporant factors that reduce the productivity of the watermelon are high temperatures, high humidity, exces rain, pests and diseases. The results obtained in our study indicate that the use of different mulch system is a potential factor in aphids control on watermelons.

The aphids' flight maximum in watermelon growth at Pula in 2008 was occurred two weeks earlier than at Opuzen $(2004,2005)$. Ten days after the planting, during the first assessment, the aphid population density was equally as the recorded maximum. That indicates the observations of the visual traps are necessary, anon after the planting, in order to create the aphids control management strategy.

The effect of different mulches on aphid populations in vegetable crops has to be continued.

\section{ACKNOWLEDGEMENT}

The authors thank head of Valtura jail who gave up part of jail farm for carrying out this experiment and prisoners who were of valuable assistance during aphid sampling.

\section{LITERATURE}

Brown, J.E., Dangle, J.M., Woods, F.M., Tilt, K.M., Henshaw, M.D., Griffey, W.A., West, M.S. 1993. Delay in mosaic virus onset and aphid vector reduction in summer squash grown on reflective mulches. HortSci., 28, 9: 895-896.

Csizinszky, A.A., Schuster, D.J., Kring. J.B. 1995. Color mulches influence yield and insect pest populations in tomatoes. J. Amer. Soc. Hort. Sci., 120, 5: 778-784.

Farias-Larios, J., Orozco-Santos, M. 1997a. Color polyethylene mulches increase fruit quality and yield in watermelon and reduce insect pest populations in dry tropics. Gartenbauwissenschaft, 62, 6: 255-260.

Farias-Larios, J., Orozco-Santos, M. 1997b. Effect of polyethylene mulch colour on aphid populations, soil temperature, fruit quality, and yield of watermelon under tropical conditions. New Zeal. J. Crop Hort., 25, 369374.

Goreta, S., Perica, S., Dumičić, G., Bučan, L., Žanić, K. 2005. Growth and yield of watermelon on polyethylene mulch with different spacings and nitrogen rates. HortSci., 40, 2: 366-369.

Johnson, J.M., Hough-Goldstein, J.A., Vangesell, M.J. 2004. Effects of straw mulch on pest insects, predators, and weeds in watermelons and potatoes. Environ. Ent., 33, 6: $1632-1643$.

Kring, J.B., Schuster, D.J. 1992. Management of insects on pepper and tomato with UV-reflective mulches. Fla. Entomol., 75, 1: 119-129.

Lamont, Jr.W.J. 1993. Plastic mulches for the production of vegetable crops. HortTehnology, 3, 1: 35-39.
Millar, I.M. 1994. A Catalogue of the Aphids (Homoptera: Aphidoidea) of Sub-Saharan Africa. Agricultural Research Council, Pretoria.

Saucke, H., Döring, T.F. 2004. Potato virus $Y$ reduction by straw mulch in organic potatoes. Ann. Appl. Biol., 144, 3: $347-355$.

Soltani, N., Anderson, J.L., Hamson, A.R. 1995. Growth analysis of watermelon plants grown with mulches and rowcovers. J. Amer. Soc. Hort. Sci., 120:1001-1009.

Stapleton, J.J., Summers, C.G. 2002. Reflective mulches for management of aphids and aphid-borne virus diseases in late-season cantaloupe (Cucumis melo L. var. cantalupensis). Crop Prot., 21, 891-898.

Summers, C.G., Mitchell, J.P., Stapleton, J.J. 2005. Mulches reduce aphid-borne viruses and whitefies in cantaloupe. Calif. Agr., 59, 2: 90-94.

Trdan, S., Žnidarčič, D., Kač, M., Vidrih, M. 2008. Yield of early white cabbage grown under mulch and non-mulch conditions with low populations of onion thrips (Thrips tabaci Lindeman). Int. J. Pest Manag., 54, 4: 309-318.

Walters, S.A. 2003. Suppression of watermelon mosaic virus in summer squash with plastic mulches and row covers. HortTehnology, 13, 2: 352-357.

White, J.M. 2003. Watermelon yield and size when grown on four mulch colors. Proc. Fla. State Hort. Soc., 116: 138139.

White, J.M. 2004. Summer squash yield and fruit size when grown on eight mulch colors in central Florida. Proc. Fla. State Hort. Soc., 117: 56-58. 